\title{
New species of Auritella (Inocybaceae) from Cameroon, with a worldwide key to the known species
}

\author{
P. Brandon Matheny ${ }^{1}$, Terry W. Henkel ${ }^{2}$, Olivier Séné ${ }^{3}$, Hailee B. Korotkin ${ }^{1}$, Bryn T.M. Dentinger ${ }^{4}$, and M. Catherine Aime ${ }^{5}$
}

1'Department of Ecology and Evolutionary Biology, University of Tennessee, 569 Dabney Hall, Knoxville, TN 37996-1610, USA; corresponding author e-mail: pmatheny@utk.edu

${ }^{2}$ Department of Biological Sciences, Humboldt State University, 1 Harpst St., Arcata, CA 95521, USA

${ }^{3}$ Institute of Agricultural Research for Development, National Herbarium of Cameroon, PO Box 1601, Yaoundé, Cameroon

${ }^{4}$ Utah Museum of Natural History and Department of Biology, University of Utah, Salt Lake City, UT 84112, USA

${ }^{5}$ Department of Botany and Plant Pathology, Purdue University, West Lafayette, IN 47907, USA

\begin{abstract}
Two new species in the genus Auritella (Inocybaceae) are described as new from tropical rainforest in Cameroon. Descriptions, photographs, line drawings, and a worldwide taxonomic key to the described species of Auritella are presented. Phylogenetic analysis of 28S rDNA and rpb2 nucleotide sequence data suggests at least five phylogenetic species that can be ascribed to Auritella occur in the region comprising Cameroon and Gabon and constitute a strongly supported monophyletic subgroup within the genus. Phylogenetic analysis of ITS data supports the conspecificity of numerous collections attributed to the two new species as well as the monophyly of Australian species of Auritella. This work raises the known number of described species of Auritella to thirteen worldwide, four of which occur in tropical Africa, one in tropical India, and eight in temperate and tropical regions of Australia. This is the first study to confirm an ectomycorrhizal status of Auritella using molecular data.
\end{abstract}

Key words:

Africa

Agaricales

ectomycorrhizas

Gilbertiodendron

Guineo-Congolian rainforest systematics

tropics

Article info: Submitted: 20 July 2017; Accepted: 13 October 2017; Published: 18 October 2017.

\section{INTRODUCTION}

Eleven species of the mushroom genus Auritella (Inocybaceae, Agaricales) are currently recognized. The generic name was originally published in 2006 and now encompasses taxa discovered in Africa, Australia, and India (Matheny \& Bougher 2006a, b, 2017, Matheny et al. 2012). Species of Auritella are united morphologically by their smooth and typically yellowish brown pigmented basidiospores, long or elongated cheilocystidia, necropigmented basidia, often tough flesh, absence of pleurocystidia, and paleotropical and Australian distribution. In addition, all known Auritella species are putatively ectomycorrhizal (ECM), occurring on or in soil in the vicinity of ECM trees of Myrtaceae, Fabaceae, Casuarinaceae, and Dipterocarpaceae, and share a distinct phylogenetic position as one of seven major clades in the family Inocybaceae (Matheny 2009, Matheny et al. 2009). The genus, as currently known, has a restricted, partial Gondwanan geographical distribution, occurring in tropical regions of Africa and India and temperate and tropical areas of Australia. Tropical African and Indian species are distinguished by their typically long stipe, scaly pileus and often scaly stipe surfaces, bright basidiome colours, trichoderm pileipellis, thick-walled cheilocystidia composed of chains of hyphal cells, and occurrence in lowland tropical rainforest. In contrast, Australian species are dull in colour, several have a squat habit, are felty tomentose to fibrillose in surface texture, the cheilocystidia are thin-walled, and most (six of eight known species) are distributed in temperate forest regions.

During recent mycological expeditions to the Dja Biosphere Reserve in southeastern Cameroon, we collected $>250$ morphospecies of putatively ECM macrofungi in monodominant forests of the ECM tree Gilbertiodendron dewevrei (Fabaceae subfam. Caesalpinioideae; e.g. Buyck et al. 2016, Castellano et al. 2016a, b). Several of the putative morphospecies referable to Inocybaceae were found to be noteworthy as subsequent determinations placed these in Auritella. Here we describe two of these as new species.

This work raises the known number of described species of Auritella from Africa to four, but recognizes at least five phylogenetic lineages that correspond to species, all of which are known only from the Guineo-Congolian rainforests of Cameroon and Gabon in Central Africa. Phylogenetic analyses of 28S-rRNA, rpb2 and the ITS gene region are presented, along with morphological descriptions, illustrations, and discussion of the new species relative to other species of Auritella recognized from Africa, India, and Australia. Historical biogeographic scenarios are also discussed.

\section{2017 International Mycological Association}

You are free to share - to copy, distribute and transmit the work, under the following conditions:

Attribution: $\quad$ You must attribute the work in the manner specified by the author or licensor (but not in any way that suggests that they endorse you or your use of the work).

Non-commercial: You may not use this work for commercial purposes.

No derivative works: You may not alter, transform, or build upon this work.

For any reuse or distribution, you must make clear to others the license terms of this work, which can be found at http://creativecommons.org/licenses/by-nc-nd/3.0/legalcode. Any of the above conditions can be waived if you get permission from the copyright holder. Nothing in this license impairs or restricts the author's moral rights. 


\section{MATERIAL AND METHODS}

\section{Field collections}

Basidiomata were collected in Cameroon during the Aug.Sept. early rainy season of 2014 and the Nov.-Dec. late rainy season of 2016 from the Dja Biosphere Reserve, Northwest Sector, near the village of Somalomo, Upper Dja River Basin, within a $2 \mathrm{~km}$ radius of a base camp located at $3^{\circ} 21^{\prime} 29.8^{\prime \prime}$ $\mathrm{N}$; 12 43'46.9" W, $650 \mathrm{~m}$ a.s.l., in forests dominated by Gilbertiodendron dewevrei (Peh et al. 2014). Descriptions of macromorphological features were made from fresh material in the field. Colours were compared with plates in Kornerup \& Wanscher (1978) and are cited in parentheses (e.g. 7F7). Fresh specimens were photographed in the field laboratory. "L" refers to the number of lamellae that reach the stipe. After documentation basidiomata were dried with silica gel.

Dried basidiomata were sectioned and rehydrated in $3 \% \mathrm{KOH}$ in order to examine and measure anatomical features following Matheny \& Bougher (2006a, 2017) on a Nikon Eclipse 80i compound microscope using NIS Elements (D) imaging software. In the taxonomic descriptions, mean basidiospore dimensions are italicized, and $Q$ refers to the quotient of the length of basidiospores divided by their width.

Holotypes and duplicate collections of African materials are deposited in the Cameroon National Herbarium (YA); isotypes and other duplicates are deposited in HSC, TENN, PUL and/or UT.

\section{DNA extractions, PCR amplification, and sequencing}

Procedures for DNA extractions, PCR, and direct sequencing are detailed in Judge et al. (2010) and Baroni \& Matheny (2011). As in the latter work, we sequenced both ITS1 and ITS2 and the intervening 5.8S ribosomal RNA gene (ITS), the 5' portion (initial 700-1350 bp) of the nuclear encoded large subunit ribosomal RNA (28S), and the most variable region between conserved domains six and seven of the RNA polymerase II second largest subunit (rpb2 gene). PCR and sequencing primers used in this work are the same as those used and cited in Judge et al. (2010) and Baroni \& Matheny (2011).

\section{DNA sequence alignments and phylogenetic analyses}

To infer the phylogenetic placement of Auritella species, we assembled separate alignments of $3728 \mathrm{~S}$ and $27 \mathrm{rpb} 2 \mathrm{DNA}$ sequences from on-going and much more taxonomically inclusive gene datasets in MacClade v4.08a (Maddison \& Maddison 2005), including two 28S sequences (JQ657775, JQ657772) produced from Auritella species as "Inocybe" by Tedersoo et al. (2012), and one 28S sequence (FR731774) from a caesalpinoid (Fabaceae) ectomycorrhiza (Tedersoo et al. 2011) (Table 1). These latter sequences showed high similarity to Auritella sequences after blast searches at NCBI. Auritella isolates and outgroup sequences of Crepidotus were pruned and saved as separate nexus files for both gene regions. Crepidotus was used as the outgroup for rooting purposes following Matheny et al. (2006, 2009, 2012). All aligned characters were maintained in each file, however, the intron 4 region of rpb2 (Matheny 2005) was excluded prior to phylogenetic analysis. After homogenizing the taxon lists in both datasets, we converted the files to phylip format using SeaView v3.2 (Galtier et al. 1996, Gouy et al. 2010).

ITS data from 32 samples were aligned using Clustal $X$ 2.0.9 (Larkin et al. 2007) and manually adjusted in MacClade. Sites deemed too ambiguous to align were removed before phylogenetic analysis. Auritella foveata was used to root the ITS tree based on the combined $28 \mathrm{~S}+r p b 2 \mathrm{ML}$ tree result. All ITS sequences used in this study are included in Table 1.

Models of molecular evolution for each data set used a GTR model of a DNA substitution matrix and a GAMMA model of rate heterogeneity under the Maximum Likelihood (ML) criterion in RAxML v7.2.8 (Stamatakis 2006) or RAxML v8.0.0 (Stamatakis 2014) following recommendations in the RAxML user manual. 1000 rapid bootstraps were performed. Bootstrap proportions $>70 \%$ were considered as evidence of strong support for phylogenetic groupings. After determination of no strongly supported inter-gene conflict, both $28 \mathrm{~S}$ and rpb2 gene regions were concatenated in MacClade and saved as a phylip formatted data set in SeaView. A RAxML analysis with 1000 bootstraps was performed again following the procedures above after partitioning the data by the $28 \mathrm{~S}$ region and each codon position. Due to high divergence of the ITS between $A$. aureoplumosa and $A$. foveata, the ITS alignment was analyzed separately and not concatenated with the 28S+rpb2 alignment. Nexus files and bipartitions tree files are available at http://mathenylab.utk.edu/Site/ Alignments_\%26_Data_Sets.html or from the lead author upon request. New DNA sequences have been submitted to GenBank.

\section{RESULTS}

Thirty-seven new sequences were submitted to GenBank (accession nos. KT378200-KT378216, MF374757-MF374768, MF474176, and MF476239-MF476241). These are shown in bold, with additional details, in Table 1. The final concatenated data set of $28 S$ and rpb2 sequences included 37 taxa and 2155 included sites. The 28S partition included sequence data for all 37 taxa and 1434 sites. The rpb2 partition included sequence data for 27 taxa and 721 sites.

The genus Auritella was strongly supported as monophyletic consistent with prior studies with more extensive taxon sampling (Matheny et al. 2009, 2012) (Fig. 1). Within Auritella, three major subgroupings were recovered that correspond to continental divisions: (1) a deeply diverging lineage composed of a single branch represented by the tropical Indian species, $A$. foveata, which is sister to all remaining Auritella lineages with strong support; (2) a group of five species-level lineages from tropical Africa (Cameroon and Gabon); and (3) a weakly supported group of nine species-level Australian taxa (Matheny \& Bougher 2017).

Group 2 included two new species described here from Cameroon, A. hispida and A. spiculosa, that formed a strongly supported monophyletic group but are distinguished from each other mainly by basidiospore shape and size and divergences at all genetic loci examined. The Afro-tropical $A$. aureoplumosa formed a strongly supported group with two insufficiently identified GenBank $28 \mathrm{~S}$ sequences produced 
Table 1. Taxa, vouchers, geographic origin, and DNA sequences of Auritella and Crepidotus used in this study. All types indicated are holotypes. New sequences produced by this work are in bold.

\begin{tabular}{|c|c|c|c|c|c|}
\hline \multirow[t]{2}{*}{ Species } & \multirow[t]{2}{*}{ Specimen-voucher (Collection) } & \multirow[t]{2}{*}{ Geographic origin } & \multicolumn{3}{|c|}{ GenBank accession no. } \\
\hline & & & ITS & nLSU & rpb2 \\
\hline A. arenicolens & OKM23824 (PERTH) & Western Australia & MF474176 & MF476239 & MF490438 \\
\hline A. arenicolens & E5465 (PERTH) & Western Australia & KT382278 & KT378209 & KT378216 \\
\hline A. arenicolens & NLB412 (PERTH) & Western Australia & JX258833 & KT378211 & - \\
\hline A. arenicolens & KS540/92 (PERTH) & Western Australia & MF374757 & - & - \\
\hline A. "arenicolens" & KS1873/07 (PERTH) & Western Australia & KJ729857 & KJ702338 & KJ729920 \\
\hline A. aureoplumosa & Wat23132 (E; type) & Cameroon & - & AY635766 & - \\
\hline A. "aureoplumosa" & Wat26727 (E) & Cameroon & KT378200 & - & - \\
\hline A. aureoplumosa & L5206_Inoc_Cam02 (ectomycorrhiza) & Cameroon & - & FR731774 & - \\
\hline A. brunnescens & PBM3173 (TENN) & New South Wales & KJ702343 & JQ313558 & KJ702348 \\
\hline A. brunnescens & PBM3174 (TENN) & New South Wales & KJ702344 & JQ313571 & KJ702349 \\
\hline A. brunnescens & PBM3721 (TENN) & Queensland & KJ702345 & KJ702340 & KJ702350 \\
\hline A. brunnescens & NLB942 (PERTH; type) & Queensland & KJ702342 & KJ702339 & KJ702347 \\
\hline A. brunnescens & NLB963 (TENN) & Queensland & KJ702346 & KJ702341 & KJ702351 \\
\hline A. chamaecephala & PBM2212 (TENN) & Western Australia & - & AY635765 & AY635781 \\
\hline A. chamaecephala & NLB1079 (PERTH) & Western Australia & KT378201 & KT378205 & KT378212 \\
\hline A. dolichocystis & T24844 (WTU) & New South Wales & - & AY380371 & AY337371 \\
\hline A. dolichocystis & T24843 (WTU) & New South Wales & - & AY635764 & AY635780 \\
\hline A. dolichocystis & T24838 (PERTH; type) & New South Wales & - & AY635763 & AY635767 \\
\hline A. foveata & TBGT9631 (TENN; type) & Kerala & GU062740 & GU062739 & GU062738 \\
\hline A. fulvella & AQ669485 (BRI) & Queensland & KJ702355 & KJ702353 & KJ702357 \\
\hline A. fulvella & AQ669492 (BRI; type) & Queensland & KJ702354 & KJ702352 & KJ702356 \\
\hline A. fulvella & MEL2382701 & Northern Territory & KP012880 & KT378210 & - \\
\hline A. geoaustralis & H7344 (PERTH, type) & Western Australia & - & AY380395 & AY333774 \\
\hline A. hispida & TH9857 (YA) & Cameroon & KT378202 & KT378208 & KT378213 \\
\hline A. hispida & TH10009 (YA) & Cameroon & KT378203 & KT378207 & KT378215 \\
\hline A. hispida & TH10291 (YA) & Cameroon & MF374758 & - & - \\
\hline A. hispida & TH10317 (YA) & Cameroon & MF374759 & - & - \\
\hline A. hispida & TH10331 (YA) & Cameroon & MF374760 & - & - \\
\hline A. hispida & TH10354 (YA) & Cameroon & MF374761 & - & - \\
\hline A. hispida & TH10379 (YA; type) & Cameroon & MF374762 & MF476240 & - \\
\hline A. robusta & I163 (HO; type) & Tasmania & KJ702359 & KJ702358 & KJ702357 \\
\hline A. serpentinocystis & PBM3188 (TENN) & New South Wales & KJ729858 & JQ313559 & KJ756402 \\
\hline A. serpentinocystis & T25080 (PERTH; type) & New South Wales & - & AY038325 & AY333773 \\
\hline A. spiculosa & MCA7031 (YA) & Cameroon & MF374763 & - & - \\
\hline A. spiculosa & TH9866 (YA) & Cameroon & KT378204 & KT378206 & KT378214 \\
\hline A. spiculosa & TH10292 (YA) & Cameroon & MF374764 & - & - \\
\hline A. spiculosa & TH10303 (YA) & Cameroon & MF374765 & - & - \\
\hline A. spiculosa & TH10316 (YA; type) & Cameroon & MF374766 & MF476241 & - \\
\hline A. spiculosa & TH10332 (YA) & Cameroon & MF374767 & - & - \\
\hline A. spiculosa & TH10372 (YA) & Cameroon & MF374768 & - & - \\
\hline "Inocybe" sp. & TU112047 & Gabon & - & JQ657772 & - \\
\hline "Inocybe" sp. & TU112061 & Gabon & - & JQ657775 & - \\
\hline C. cf. applanatus & PBM717 (WTU) & Washington & - & AY380406 & AY333311 \\
\hline C. crocophyllus & PBM3047 (TENN) & California & - & GQ893025 & - \\
\hline C. mollis & PBM1036 (WTU) & Washington & - & DQ986293 & - \\
\hline C. versutus & PBM856 (WTU) & Washington & - & AY820890 & AY333312 \\
\hline Crepidotus sp. & PBM3237 (TENN) & Tasmania & - & KT382279 & KT382280 \\
\hline Crepidotus sp. & PBM3463 (TENN) & Western Australia & - & HQ728538 & HQ728540 \\
\hline
\end{tabular}




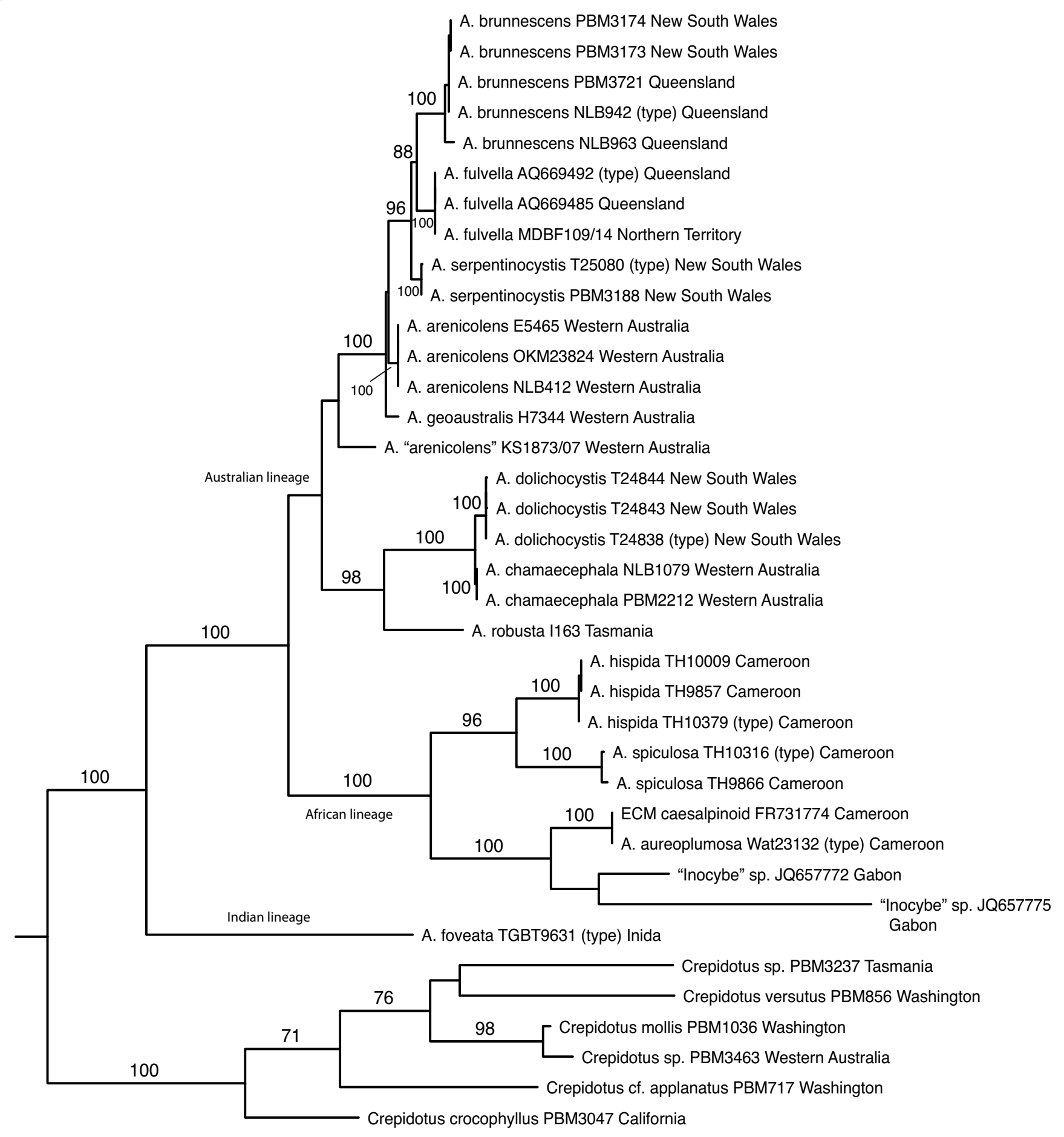

0.2 expected substitutions per site

Fig. 1. ML phylogeny of Auritella inferred from analysis of combined $28 \mathrm{~S}$ and $r p b 2 \mathrm{DNA}$ sequences. Bootstrap values $>70 \%$ are shown above or below corresponding branches. Three general lineages are indicated: Indian, African, and Australian. Crepidotus is used to root the tree.

from basidiomata labeled as "Inocybe" from Gabon.

The ITS alignment contained 728 sites, of which 589 were included for phylogenetic analysis. The ITS ML tree (Fig. 2) demonstrates: (1) the conspecificity of seven collections each of $A$. hispidia and $A$. spiculosa and their reciprocal monophyly; and (2) strong support for the monophyly of Australian species of Auritella. The taxon labeled "A. aureoplumosa" in this tree, based on collection Wat26727, is not the same as the type; its taxonomic status remains unclarified and attempts to obtain $28 \mathrm{~S}$ sequences from this collection failed.

This is also the first work to confirm an ECM status for Auritella, evidenced by the insufficiently identified caesalpinoid ectomycorrhiza 28S sequence FR731774 (Tedersoo et al. 2011) being identical to the $28 \mathrm{~S}$ sequence of the type of $A$. aureoplumosa (Fig. 1). 


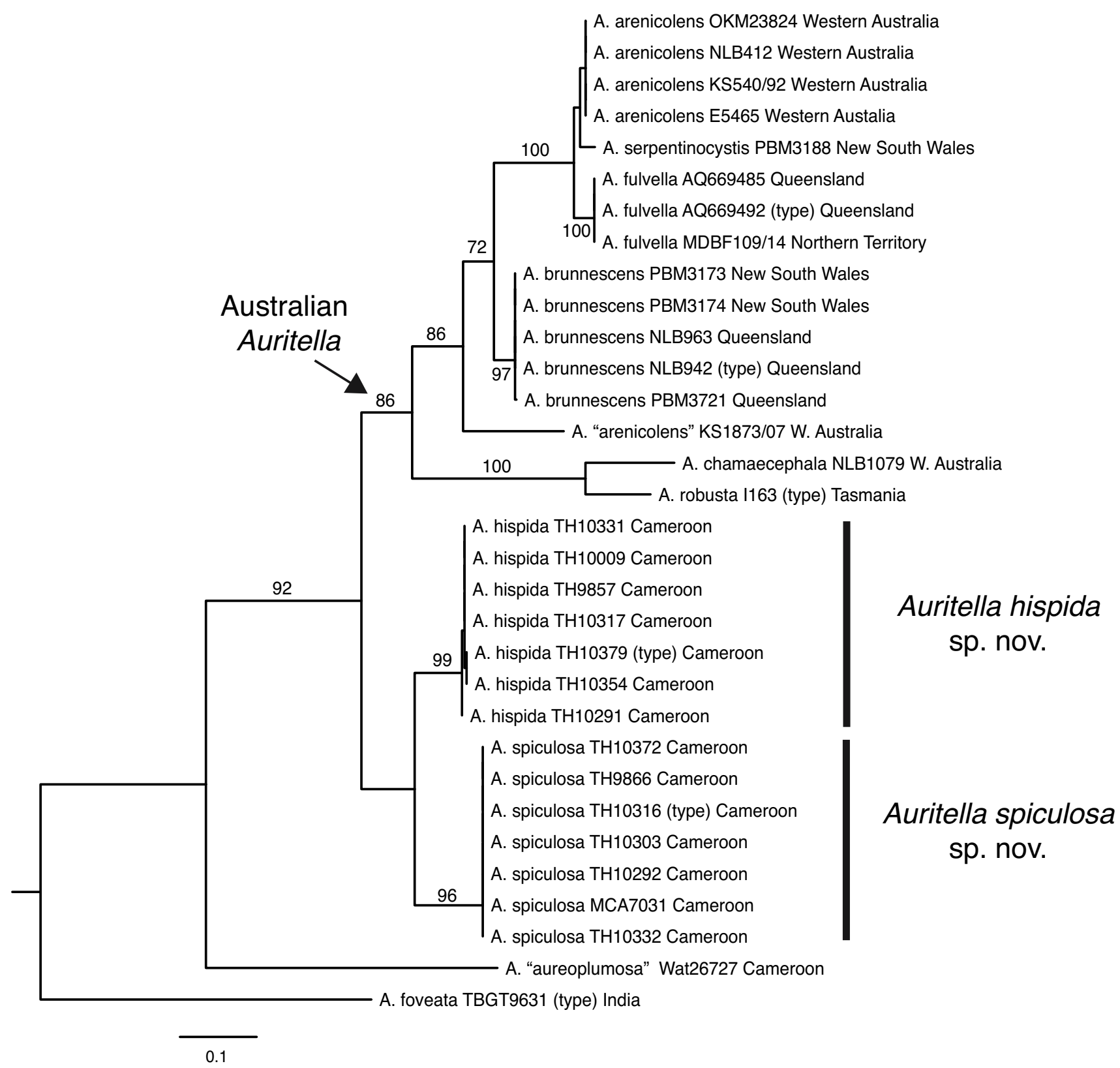

Fig. 2. ML phylogeny of Auritella inferred from analysis of ITS data. Bootstrap values $>70 \%$ are shown above or below corresponding branches. Auritella foveata is used to root the tree.

\section{TAXONOMY}

Auritella hispida Matheny \& T.W. Henkel, sp. nov. MycoBank MB814020

(Figs 3A, 4A-B, 5A-C)

Etymology: hispidus (L. adj. A), covered with coarse rigid erect hairs or bristles, in reference to the erect, acuminate vesture on the pileus and stipe surfaces.

Diagnosis: Differs from other African species of Auritella in the following ways: from $A$. spiculosa (described below) by the stipe lacking lilac tinges at the base and the broadly elliptic to subglobose basidiospores, these $6-8 \mu \mathrm{m} \times 5-7$ $\mu \mathrm{m}$ in size; differs from $A$. aureoplumosa by the thinner stipe (1.5-3.5 mm wide) and attached lamellae; and differs from 

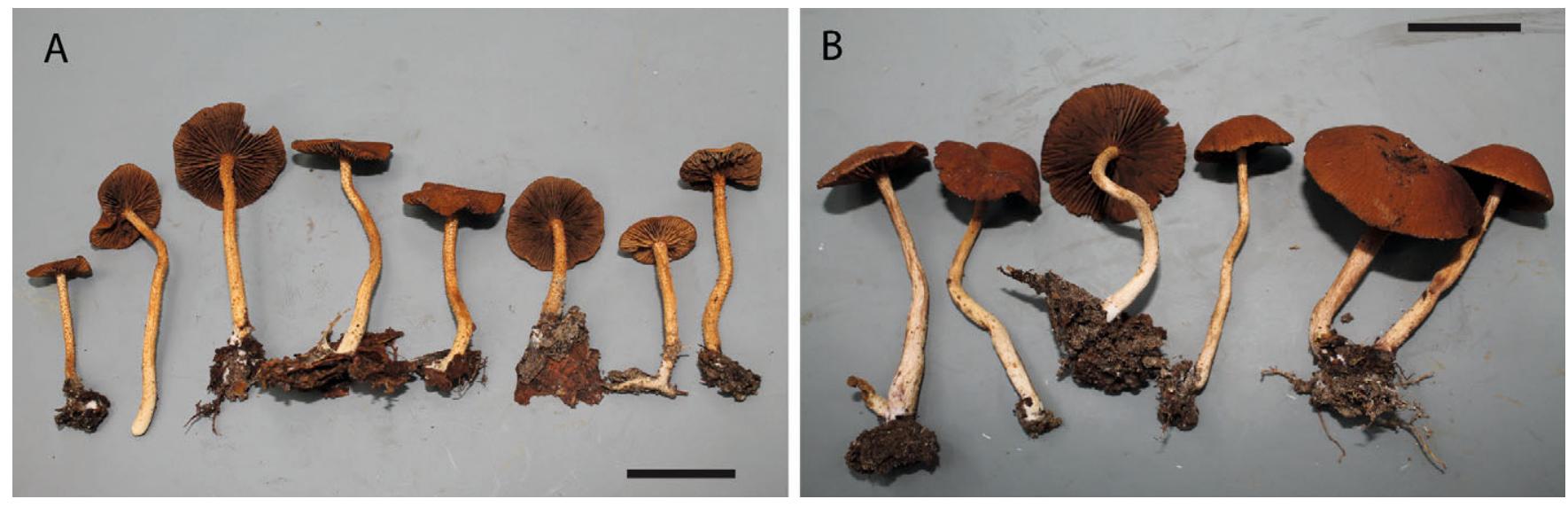

Fig. 3. Basidiomata of new Auritella species from Cameroon. A. Auritella hispida (holotype, TH10379). B. Auritella spiculosa (holotype, TH10316). Bars $=10 \mathrm{~mm}$.

to finely scabrous, under a hand lens initially with dense, contiguous, erect tuft-like fascicles, these separating with age into more discrete, acuminate, 4-5-sided pyramidal squamules with dark brown tips throughout, with intervening ground contrastingly lighter concolourous, nowhere rimose, occasionally glabrescent with age; dark brown (7F7-F8, 7E8-F8) throughout, occasionally lighter concolourous towards the margin with age, somewhat hygrophanous upon air-drying; context dull orange-tan, unchanging where cut or bruised, ca. $1 \mathrm{~mm}$ thick under the disc. Lamellae moderately close, ca. 25-30 L reaching the stipe, somewhat thick; adnate with a short decurrent tooth; brown (6E6-E8) to dark brown (6F7) with age; edges orangish brown with superimposed discrete, dark brown, fimbriate clusters visible under a hand lens, unchanging with pressure. Stipe 36-60(-87) x 1.5-3.5 mm, equal; surface dry, densely scabrous-hispid, with acuminate erect to decurved fascicles visible under a hand lens, these mostly lighter concolourous with the ground colour, occasionally darker; extreme apex with dark pruinae contiguous with lower inner lamellar edges; light brown (6D5D6-D7) overall; basal mycelium white, extending into litter materials below; context concolourous orange-tan, fibrous, with a narrow hollow central core extending from the apex to the base. Odour none. Taste faintly sweet initially, quickly to mealy or indistinct.

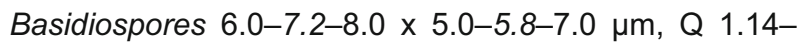
1.26-1.40 $(n=36 / 2)$ smooth, broadly elliptic to subglobose with rounded apices, apiculus small but often distinct, yellowish brown with a slightly thickened wall, coffee brown (5E7) in deposit. Basidia 27-40 x 6-8 $\mu \mathrm{m}, 4$-sterigmate, slenderly clavate to narrowly cylindric, necropigmented, sterigmata often pronounced, to $6 \mu \mathrm{m}$ long and 1.5-2.0 $\mu \mathrm{m}$ wide at the base. Pleurocystidia absent. Cheilocystidia 35-65 x 8-18 $\mu \mathrm{m}$ (terminal cells), occurring in scattered but projecting pyramidal or subpyramidal chains on the edges of the lamellae when viewed at $100 x$ without a coverslip, terminal cells most often fusiform to broadly fusiform or ventricose, bladder-shaped, or clavate; cells tawny, smooth, thick-walled (1.0-3.0 $\mu \mathrm{m}$ thick); subtending cells often apically swollen and tapered towards the base with similar pigmentation and thick walls as the terminal cells, however, the thick-walled and pigmented state develops from a thin- walled hyaline state. Caulocystidia absent; stipe surface composed of broad trichodermially arranged bundles of hyphae, these forming chains of often cylindric, thick-walled (1.0-2.5 $\mu \mathrm{m}$ thick), brownish yellow cells (occasional chains hyaline and thin-walled) with frequent septa, the end cells of which are cylindric to slenderly fusiform, 9-15 $\mu \mathrm{m}$ wide; base of stipe covered with similar hairs, occasionally with faint incrustations. Pileipellis a trichoderm composed of scattered fascicles of cylindric hyphae, these yellowish-brown to tawny in mass and frequently septate, walls $1.0-2.0 \mu \mathrm{m}$ thick; terminal cells poorly differentiated, occasionally with faint incrustations. Clamp connections present.

Habit, habitat, and distribution: Solitary or scattered in small groups, on soil in wet tropical rainforest in monodominant stands of Gilbertiodendron dewevrei, August to December; known only from the type locality in the Dja River Basin of southeastern Cameroon.

Additional specimens examined: Cameroon: East Region: Dja Biosphere Reserve, northwest sector near Somalomo Village, Upper Dja River Basin, with $2 \mathrm{~km}$ radius of Dja base camp, $3^{\circ} 21^{\prime} 29.8^{\prime \prime}$ $\mathrm{N}, 12^{\circ} 43^{\prime} 46.9^{\prime \prime} \mathrm{W}$, elev. $650 \mathrm{~m}, 0.6 \mathrm{~km} \mathrm{~W}$-SW of base camp in GD plot 1, in monodominant Gilbertiodendron dewevrei stand, 16 Aug. 2014, T.W. Henkel TH 9857 (YA, TENN 070318, HSC G1213); 24 Sep. 2014, T.W. Henkel TH 10009 (TENN 070319, HSC G1185); $1.4 \mathrm{~km}$ SW-W from base camp in GD plot 2, in monodominant Gilbertiodendron dewevrei stand, 14 Nov. 2016, T.W. Henkel TH 10260 (YA, TENN 071619, HSC G1205); loc. cit. 18 Nov. 2016, T.W. Henkel TH 10274 (YA, TENN 071620, HSC G1211); loc. cit. 18 Nov. 2016, T.W. Henkel TH 10276 (YA, TENN 071621, HSC G1214); loc. cit. 20 Nov. 2016, B.T.M. Dentinger BD651a (UT M0000001, TENN 071606); loc. cit. 21 Nov. 2016, M.C. Aime MCA 7046 (YA, TENN 071610, PUL F3759); loc. cit. 23 Nov. 2016, T.W. Henkel TH 10291 (YA, TENN 071622, HSC G1206); loc. cit. 29 Nov. 2016, T.W. Henkel TH 10317 (YA, TENN 071623, HSC G1207); loc. cit. 2 Dec. 2016, T.W. Henkel TH 10331 (YA, TENN 071624, HSC G1208); 6 Dec. 2016, T.W. Henkel TH 10354 (YA, TENN 071625, HSC G1212); loc. cit. 11 Dec. 2016, T.W. Henkel TH 10380 (YA, TENN 071627, HSC G1209); loc. cit. 12 Dec. 2016, T.W. Henkel TH 10381 (YA, TENN 071628, HSC G1210). 


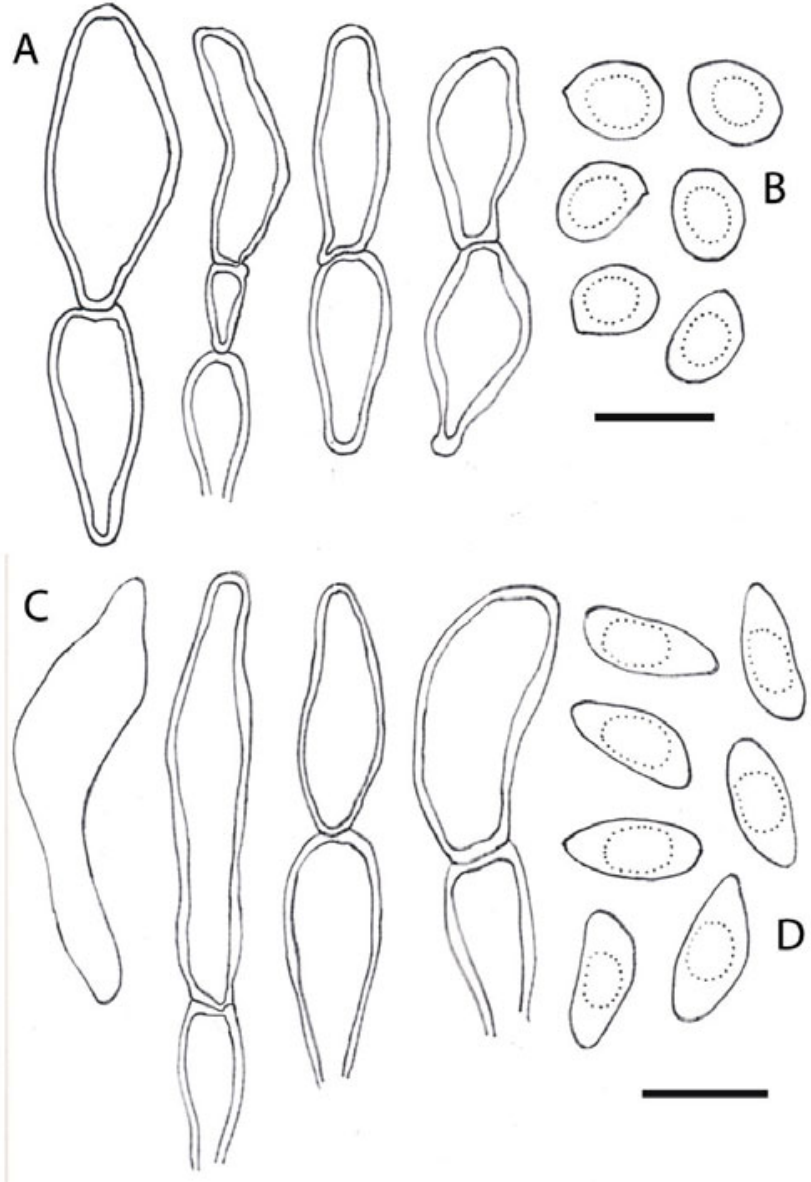

Fig. 4. Microscopic features of Auritella hispida (holotype, TH10379), top, and A. spiculosa (holotype, TH10316), bottom. A. Cheilocystidia of $A$. hispida. B. Basidiospores of $A$. hispida. C. Cheilocystidia of $A$. spiculosa. D. Basidiospores of $A$. spiculosa. Bars $=10 \mu \mathrm{m}$.

Comments: Auritella hispida shares a close phylogenetic relationship with $A$. spiculosa (Figs 1-2) described below. The two species also closely resemble each other in terms of their gross morphology. However, the stipe base in A. spiculosa has been observed with lilac tones, a feature lacking in A. hispida. In addition, A. hispida appears to have a more densely scabrous-hispid stipe surface than $A$. spiculosa. These differences, however, may be subtle. The most reliable way to distinguish the two species is by basidiospore shape and size. The basidiospores of $A$. hispida are broadly elliptic to subglobose and measure $6.0-8.0 \times 5.0-7.0 \mu \mathrm{m}$, whereas those of $A$. spiculosa are oblong-amygdaliform to cylindric and measure 9.0-11.5 x 4.5-5.5 $\mu \mathrm{m}$. Specimens of both species produce basidiomes near each other in the same localities and can result in mixed collections if individual specimens are not examined microscopically for spore shape and size. ITS, 28S, and rpb2 DNA sequences readily distinguish the two species as well.

Auritella aureoplumosa (Watling 2001, Matheny \& Bougher 2006a), also described from Cameroon, is distinguished from $A$. hispida by several features including free lamellae, the presence of rich tawny orange scales that girdle the wider stipe, and by the divergent 28S DNA sequence produced from the type collection. The shape and size of the basidiospores in A. aureoplumosa (subglobose,
6.5-8.0 x 5.5-6.5 $\mu \mathrm{m}$ ) are very similar to those of $A$. hispida, but differences in attachment of the lamellae, stipe width and texture, and DNA sequences readily distinguish the two. Auritella erythroxa (De Seynes 1897, Matheny \& Bougher 2006a), described from Gabon, is known only from the protologue but can be distinguished from $A$. hispida by the smaller basidiospores $(7.0 \times 3.0-4.0 \mu \mathrm{m})$ and smooth stipe. We are unaware if a type collection of this species is extant.

Auritella spiculosa Matheny \& T.W. Henkel, sp. nov. MycoBank MB814021

(Figs 3B, 4C-D, 5D-F)

Etymology: spiculosus (L. adj. A), covered with spicules or fine points, in reference to the vesture of the stipe surface composed of erect acuminate scales.

Diagnosis: Differs from other African species of Auritella in the following ways: from $A$. hispida (described above) by the stipe with lilac tinges at the base and the oblong-amygdaliform to cylindric basidiospores, these 9-11.5 x 4.5-5.5 $\mu \mathrm{m}$ in size; differs from $A$. aureoplumosa by the thinner stipe size (mostly 2-4 mm wide) and attached lamellae; and differs from $A$. erythroxa in the scaly stipe surface and oblong-amygdaliform to cylindric basidiospores.

Type: Cameroon: East Region: Dja Biosphere Reserve, northwest sector near Somaloma Village, Upper Dja River Basian, within $2 \mathrm{~km}$ radius of Dja base camp, $3^{\circ} 21^{\prime} 29.8^{\prime \prime}$ $\mathrm{N}, 12^{\circ} 43^{\prime} 46.9^{\prime \prime} \mathrm{W}$, elev. $650 \mathrm{~m}, 1.4 \mathrm{~km}$ SW-W from base camp in GD plot 2, under Gilbertiodendron dewevrei in a monodominant stand of this species, 29 Nov. 2016, T.W. Henkel TH 10316 (YA 66933 - holotype; TENN 071616, HSC G1215 - isotypes).

Description: Pileus 13-38(-48) mm wide, 4-12 mm high, broadly convex to nearly plane, occasionally with broadly wavy margin with age but not uplifted; center narrowly and shallowly depressed even when young, more deeply so with age; edge finely crenulate under hand lens; surface subdry, velutinous and composed of minute erect-acuminate squamules throughout, these with light brown tips, more concentrated over the disc, slightly more separated towards the margin with faint shallow striations over marginal $1 / 3$, these extending nearly to center in older larger specimens; overall colour dark brown (7E8-7F8) throughout, slightly hygrophanous with air-drying; context concolourous dark brown, unchanging, ca. $1.5 \mathrm{~mm}$ thick below the disc. Lamellae moderately close, somewhat thick, ca. $40 \mathrm{~L}$ reaching the stipe, with several tiers of lamellulae (3-7, alternating long and short), these $2-15 \mathrm{~mm}$ long in largest specimen, adnate with a slight decurrent tooth, dull dark brown (ca. 7F6); edges dark brown with superimposed discrete, darker brown, fimbriate clusters visible to the eye and under a hand lens. Stipe (33-)40-65 x 2-4(-7) mm, equal over apical portion or occasionally throughout, usually widening gradually over basal $1 / 3$ to $5-7(-10) \mathrm{mm}$, overall brownish orange (ca. 6C3$6 \mathrm{C} 4)$; surface over apical $4 / 5$ with minute, erect-acuminate fascicles, these tan-brown and lighter than the ground colour under a hand lens, less dense over lower 1/5; extreme 

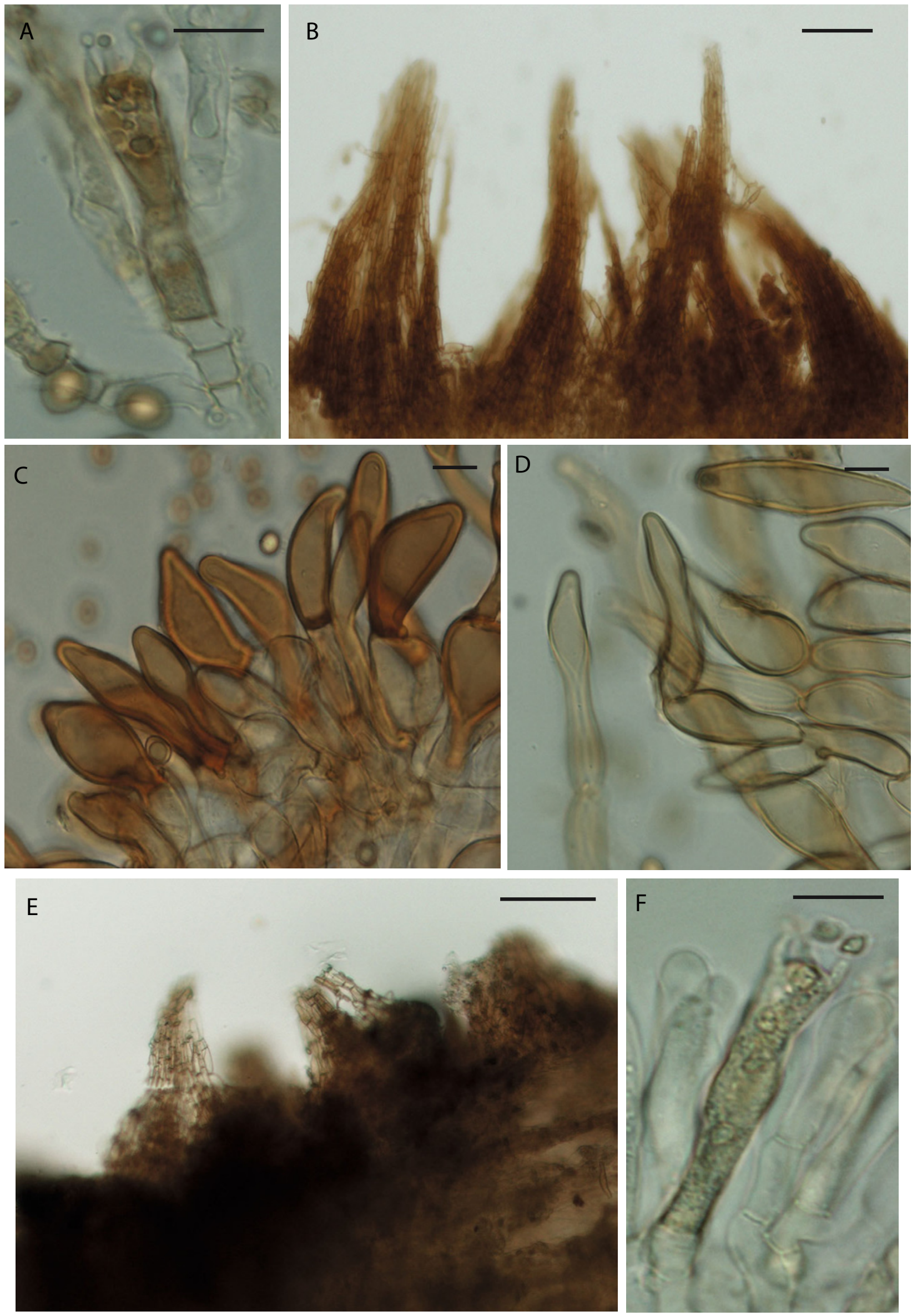

Fig. 5. Microscopic features of Auritella hispida (holotype, TH10379), A-C, and A. spiculosa (holotype, TH10316), D-F). A. Necropigmented basidium. Bar $=10 \mu \mathrm{m}$. B. Trichoderm pileipellis. Bar $=100 \mu \mathrm{m}$. C. Cheilocystidia. Bar $=10 \mu \mathrm{m}$. D. Cheilocystidia. Bar $=10 \mu \mathrm{m}$. E. Trichoderm pileipellis. Bar $=100 \mu \mathrm{m}$. F. Necropigmented basidium. Bar $=10 \mu \mathrm{m}$. 
apex with dark brown, recurved scales; basal mycelium a dense white bloom over extreme base, this often with faint lavender tones in younger specimens; context concolourous light brown, unchanging where cut or bruised, longitudinally fibrous, with a narrow, hollow central core usually extending from the apex to the base. Odour slightly farinaceous, disagreeable. Taste mild, indistinct, with mealy texture.

Basidiospores (8.5-)9.0-10-11.5 4.5-4.9-5.5 $\mu \mathrm{m}, \mathrm{Q}$ $=1.7-2.08-2.56 \quad(n=53 / 2)$, smooth, oblong-amygdaliform to cylindric, occasionally weakly angular or with a ventral depression, yellowish brown in $\mathrm{KOH}$, apices pointed, apiculus not distinctive, wall slightly thickened, coffee brown (5E-F7) in deposit. Basidia 40-45 x 8-9 $\mu \mathrm{m}, 4$-sterigmate, slenderly clavate to nearly cylindric, necropigmented, sterigmata often pronounced up to $6.5 \mu \mathrm{m}$ long and $1.5-2.0 \mu \mathrm{m}$ wide at the base. Pleurocystidia absent. Cheilocystidia 42-80 x 8-17 $\mu \mathrm{m}$, forming chains of frequently septate hyphae, the terminal cells often ventricose, saccate, cylindric or irregularly so, tawny or hyaline, thick-walled (walls 1.0-2.5 $\mu \mathrm{m}$ thick), occasionally thin-walled. Caulocystidia absent; surface at stipe apex with scattered bundles of trichodermially arranged hyphal chains, these frequently septate, cylindric, thick-walled (walls ca. 2.0 $\mu \mathrm{m}$ thick), mostly $7-13 \mu \mathrm{m}$ wide, pale tawny to hyaline; lower part of stipe with a dense and interwoven superficial layer of cylindric hyphae, these thick-walled or thin-walled, hyaline or pale tawny. Pileipellis a trichoderm, at times with pyramidallike clusters of chains of cylindric hyphae, generally tawny to ochraceous tawny in mass, hyphae mostly thick-walled (1-2.5 $\mu \mathrm{m}$ thick) or occasionally thin-walled; terminal cells saccate, ventricose, or cylindric, mostly 7-18 $\mu \mathrm{m}$ wide, subterminal cells smooth, wrinkled, or occasionally incrusted. Clamp connections present.
Habit, habitat, and distribution: Solitary or scattered in small groups, on soil in wet tropical rain forest in monodominant stands of Gilbertiodendron dewevrei, August to December; known only from the type locality in the Dja River Basin of southeastern Cameroon.

Additional specimens examined: Cameroon: East Region: Dja Biosphere Reserve, northwest sector near Somalomo Village, Upper Dja River Basin, within $2 \mathrm{~km}$ radius of Dja base camp, $3^{\circ} 21^{\prime} 29.8^{\prime \prime}$ $\mathrm{N}, 12^{\circ} 43^{\prime} 46.9^{\prime \prime} \mathrm{W}$, elev. $650 \mathrm{~m}, 0.6 \mathrm{~km} \mathrm{~W}$-SW of base camp in GD plot 1, in monodominant Gilbertiodendron dewevrei stand, 16 Aug. 2014, T.W. Henkel TH 9866 (YA, TENN 070320, HSC G1216); 2 km SW of base camp in GD plot 3, in monodominant Gilbertiodendron dewevrei stand, 14 Nov. 2016, T.W. Henkel TH 10261 (YA, TENN 071611, HSC G1219); loc. cit. 15 Nov. 2016, T.W. Henkel TH 10266 (YA, TENN 071612, HSC G1217); loc. cit. 17 Nov. 2016, T.W. Henkel TH 10271 (YA, TENN 071613, HSC G1220); loc. cit. 20 Nov. 2016, M.C. Aime MCA 7031 (YA,TENN 071609, PUL F3758); loc. cit. 24 Nov. 2016, T.W. Henkel TH 10292 (YA, TENN 071614, HSC G1221); loc. cit. 26 Nov. 2016, T.W. Henkel TH 10303 (YA, TENN 071615, HSC G1222); loc. cit. 2 Dec. 2016, T.W. Henkel TH 10332 (YA, TENN 071617, HSC G1223); loc. cit. 9 Dec. 2016, T.W. Henkel TH 10372 (YA, TENN 071618, HSC G1218).

Comments: Auritella spiculosa is best distinguished morphologically from its closest relative, $A$. hispida (described above), by the oblong-amygdaliform to cylindric basidiospores, which are considerably longer and narrower than those of $A$. hispida. In the field some specimens of $A$. spiculosa exhibit a lilac tone at the base of the stipe, a feature lacking in $A$. hispida. For comparisons with $A$. erythroxa and $A$. aureoplumosa, see the key below and comments under $A$. hispida above.

\section{Key to the known species of Auritella worldwide}

Basidiomata agaricoid

2 (1) Pileus felty tomentose to fibrillose, cheilocystidia thin-walled, occurring in Australia ........................................... 3

Pileus scaly or smooth and pitted, cheilocystidia thick-walled, occurring in Africa or India .................................... 9

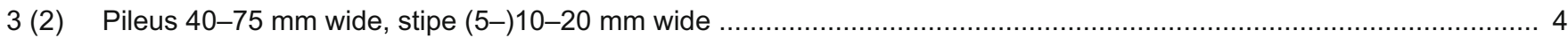

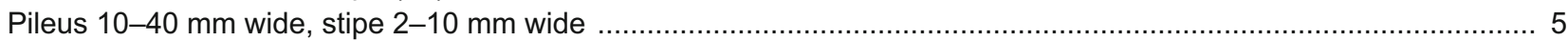

4 (3) Basidiospores long and narrow, $>10 \mu \mathrm{m}$ long

A. arenicolens (Cleland) Matheny \& Bougher 2006

Basidiospores elliptic to broadly elliptic, $<10 \mu \mathrm{m}$ long

A. robusta Matheny et al. 2017

5 (3) Cheilocystidia sinuous

Cheilocystidia slenderly clavate, sphaeropedunculate, cylindric, or fusiform, but not sinuous

6 (5) Odour not remarkable, tissues exuding yellow pigment in $\mathrm{KOH}$

A. serpentinocystis Matheny et al. ex Matheny \& Bougher 2006

Odour unpleasant, tissues not exuding yellow pigment in $\mathrm{KOH}$

A. brunnescens Matheny \& Bougher 2017

7 (5) Stipe 2-4 mm wide, mean spore Q ca. 2.00

A. fulvella Matheny \& Bougher 2017

Stipe $4-10 \mathrm{~mm}$ wide, mean spore $\mathrm{Q}$ ca. 1.80 or less 
9 (2) Pileus with a pitted surface, occurring in wet tropical forests of India

A. foveata C.K. Pradeep \& Matheny 2012

Pileus scaly, occurring in wet tropical forests of Africa (Cameroon, Gabon)

10 (9) Stipe smooth; basidiospores 7 x 3-4 $\mu \mathrm{m}$............................... A. erythroxa (De Seynes) Matheny \& Bougher 2006 Stipe girdled with scales or with fine acuminate scales or hairs; basidiospores wider than above

11 (10) Lamellae free; stipe 5-10 mm wide, with girdles of rich tawny scabrous scales

A. aureoplumosa (Watling) Matheny \& Bougher 2006

Lamellae adnate with a short decurrent tooth; stipe 1.5-4(-7) $\mathrm{mm}$ wide, scales, hairs, or fibrils on stipe usually lighter in colour than the ground colour

12 (11) Basidiospores broadly elliptic to subglobose, $6-8$ × 5-7 $\mu$ m; lilac tinges absent at stipe base

A. hispida Matheny \& T.W. Henkel 2017

Basidiospores oblong-amygdaliform to cylindric, 9-11 x 4.5-5.5 $\mu \mathrm{m}$; lilac tinges present at stipe base

A. spiculosa Matheny \& T.W. Henkel 2017

\section{DISCUSSION}

This work raises the total number of described species of Auritella to 13 worldwide, four of which, A. erythroxa, $A$. aureoplumosa, $A$. hispida, and $A$. spiculosa, are known from the wet tropical rainforest of Cameroon and Gabon. Of the remaining nine species, eight have been described from Australia and one from tropical India. In addition, two unique phylogenetic species-level lineages can also be recognized from Gabon using molecular data (Fig. 1). It is unknown whether either of these represents $A$. erythroxa, which has not been reported since it was originally described in 1897 from Gabon (Matheny \& Bougher 2006a). Overall, 15 distinct phylogenetic species-level lineages in Auritella have been detected worldwide (Fig. 1).

Auritella is a strongly supported monophyletic group, one of seven major lineages in the Inocybaceae (Matheny 2009, Matheny et al. 2009, 2012). A second major lineage, Tubariomyces (recognized as the Mallocybella clade in Matheny 2009 and Matheny et al. 2009), has been described at the generic level (Alvarado et al. 2010). Four other major clades - Inosperma, Mallocybe, Nothocybe, and Pseudosperma - have been recognized but not yet formally named at generic ranks (Matheny 2005, Matheny et al. 2009, Latha et al. 2016). Recognition of Auritella and Tubariomyces as separate genera renders Inocybe in the broad sense as a paraphyletic group but with poor support (Matheny et al. 2012). Moreover, in an analysis by Ryberg et al. (2010), constraining Inocybe as a monophyletic group with respect to Auritella produced a topology that could not be statistically rejected. Because Auritella is monophyletic we continue to place species in this genus as warranted by morphological and phylogenetic analyses. Elevation of the remaining major lineages within Inocybaceae to generic ranks remains work to be performed in the future.

Diversification within Auritella appears to have ensued on an intra-continental scale. A general area cladogram [(India, (Africa, Australia)], as interpreted based on Fig. 1, does not represent a common hierarchical biogeographic pattern found in Southern Hemisphere organisms in the strictest sense. However, the topology is consistent with optimal area cladograms of most Southern Hemisphere insects and plants, assuming extinction in other Southern Hemisphere regions (Sanmartín \& Ronquist 2004). Matheny \& Bougher (2006a) applied a strict molecular clock to the species of Auritella then known and recovered a Late Cretaceous origin (ca. 85 Mya) for the group, consistent with an ancient vicariant scenario. Matheny et al. (2009), using a relaxed molecular clock, were unable to reject a former Gondwanan distribution for Auritella as well, the crown group origin of which was estimated at 68 Mya (Late Cretaceous). However, Ryberg \& Matheny (2012) recovered a younger crown group age for the genus (ca. 40 Mya; Late Eocene), which would preclude an ancient Gondwanan vicariant distribution, but that study did not take into account the basal lineage $A$. foveata, which would push the age of the crown group further back in time. Nevertheless, the differences in estimated ages of Auritella are most likely due to differences in secondary calibration procedures between Matheny et al. (2009) and Ryberg \& Matheny (2012). Resolution of this problem is compounded by large confidence intervals surrounding the mean or median estimated crown group ages. No fossils of Auritella or other Inocybaceae are known. However, new dating analyses are needed that take more thorough taxon sampling of Auritella into account, especially the deeply diverging $A$. foveata (Matheny et al. 2012). Furthermore, ITS sequences of Auritella are highly divergent and some nucleotide regions difficult to align, suggesting some antiquity to the group or unusually high substitution rates at this locus.

Auritella has been presumed to be an ECM lineage based on observations that all species worldwide form basidiomes on soil in ectotrophic habitats (Matheny \& Bougher 2006a) and due to its phylogenetic relatedness to Inocybe, a well-known ECM lineage (Tedersoo et al. 2010). Here we found an insufficiently identified ectomycorrhiza $28 S$ sequence (FR731774) isolated from a caesalpinoid legume that is identical to the $28 \mathrm{~S}$ sequence from the type of $A$. aureoplumosa (Fig. 1; Tedersoo et al. 2011), indicating conspecificity and affirming the ECM status of the genus and the species, and presumably the genus. 


\section{ACKNOWLEDGEMENTS}

PBM is supported by US National Science Foundation (NSF) grant DEB-1354802 awarded to Matthew E. Smith (University of Florida) and PBM. The National Geographic Society's Committee for Research and Exploration grant 9235-13 and NSF DEB-1556338 provided support to TWH and BTMD, and NSF DEB-1556412 provided support to MCA. In Cameroon the Ministry of Research and Scientific Innovation issued research permits. Jean Michel Onana, former Head of The National Herbarium of Cameroon (Institute of Agricultural Research for Development, IRAD), provided much logistical assistance. The Conservators of the Dja Biosphere Reserve, Mengamenya Goue Achille and Ndinga Hillaire and their staff greatly assisted the fieldwork in the Dja. Field assistance in Cameroon was provided by Alamane Gabriel (a.k.a. Sikiro), Abate Jackson, Essambe Jean-Pierre (a.k.a. Papa Chef), Mei Lin Chin, Carolyn Delevich, Todd Elliott, Sylvain Kentsap, Jumbam Blaise, and Camille Truong. Valuable laboratory assistance was provided by Alicia Hobbs at the University of Tennessee and Rachel Koch and Elena Karlsen-Ayala at Purdue University.

\section{REFERENCES}

Alvarado P, Manjón JL, Matheny PB, Esteve-Raventós F (2010) Tubariomyces, a new genus of Inocybaceae from the Mediterranean region. Mycologia 102: 1389-1397.

Baroni TJ, Matheny PB (2011) A re-evaluation of gasteroid and cyphelloid species of Entolomataceae from eastern North America. Harvard Papers in Botany 16: 293-310.

Buyck B, Henkel TW, Dentinger BTM, Séné O, Hofstetter V (2016) Multigene sequencing provides a suitable epitype, barcode sequences and a precise systematic position for the enigmatic, African Cantharellus miniatescens. Cryptogamie, Mycologie 37: 269-282.

Castellano MA, Dentinger BTM, Séné O, Elliott TF, Truong C, Henkel TW (2016a) New Elaphomyces species (Elaphomycetaceae, Eurotiales, Ascomycota) from tropical rainforests of Cameroon and Guyana. IMA Fungus 7: 59-73.

Castellano MA, Elliott TF, Truong C, Séné O, Dentinger BTM, Henkel TW (2016b) Kombocles bakaiana gen. sp. nov. (Boletaceae), a new sequestrate fungus from Cameroon. IMA Fungus 7: 239245.

De Seynes J (1897) Recherches pour servir à l'Histoire Naturelle et à la Flore des Champignons du Congo Français. Vol. I. Paris: Masson et Cie.

Galtier N, Goy M, Gautier C (1996) SEAVIEW and PHYLO_WIN: two graphic tools for sequence alignment and molecular phylogeny. Computational and Applied Bioscience 12: 543-548.

Gouy M, Guindon S, Gascuel O (2010) SeaView 4: a multiplatform graphical user interface for sequence alignment and phylogenetic tree building. Molecular Biology and Evolution 27: 221-224.

Judge B, Ammirati JF, Lincoff G, Trestrail JH, Matheny PB (2010) Ingestion of a newly described North American mushroom species from Michigan resulting in chronic renal failure: Cortinarius orellanosus. Clinical Toxicology 48: 545-549.

Kornerup A, Wanscher JH (1978) Methuen Handbook of Color. $3^{\text {rd }}$ edn. London: Eyre Methuen.

Larkin MA, Blackshields G, Brown NP, Chenna R, McGettigan PA, et al. (2007) Clustal $W$ and Clustal $X$ version 2.0. Bioinformatics
23: 2947-2948.

Latha KPD, Manimohan P, Matheny PB (2016) A new species of Inocybe representing the Nothocybe lineage. Phytotaxa 267: 40-50.

Maddison DR, Maddison WP (2005) MacClade 4: Analysis of phylogeny and character evolution. Version 4.08a. http:// macclade.org.

Matheny PB (2005) Improving phylogenetic inference of mushrooms using RPB1 and RPB2 sequences (Inocybe, Agaricales). Molecular Phylogenetics and Evolution 35: 1-20.

Matheny PB (2009) A phylogenetic classification of the Inocybaceae. Mcllvainea 18: 11-21.

Matheny PB, Aime MC, Bougher NL, Buyck B, Desjardin DE, et al. (2009) Out of the palaeotropics? Historical biogeography and diversification of the cosmopolitan mushroom family Inocybaceae. Journal of Biogeography 36: 577-592.

Matheny PB, Bougher NL (2006a) The new genus Auritella from Africa and Australia (Inocybaceae, Agaricales): molecular systematics, taxonomy and historical biogeography. Mycological Progress 5: 2-17.

Matheny PB, Bougher NL (2006b) Validation of Auritella. Mycotaxon 98: 231-233.

Matheny PB, Bougher NL (2017) Fungi of Australia: Inocybaceae. Australian Biological Resources Study. Melbourne: CSIRO Publishing.

Matheny PB, Curtis JM, Hofstetter V, Aime MC, Moncalvo J-M, et al. (2006) Major clades of Agaricales: a multilocus phylogenetic overview. Mycologia 98: 982-995.

Matheny PB, Pradeep CK, Vrinda KB, Varghese SP (2012) Auritella foveata, a new species of Inocybaceae (Agaricales) from tropical India. Kew Bulletin 67: 119-125.

Peh KS, Sonke B, Séné O, Djuikouo MN, Nguembou CK, Taedoumg H, Begne SK, Lewis SL (2014) Mixed-forest species establishment in a monodominant forest in central Africa: implications for tropical forest invasibility. PLoS One 9: e97585.

Ryberg M, Larsson E, Jacobsson S (2010) An evolutionary perspective on morphological and ecological characters in the mushroom family Inocybaceae (Agaricomycotina, Fungi). Molecular Phylogenetics and Evolution 55: 431-442.

Ryberg M, Matheny PB (2012) Asynchronous origins of ectomycorrhizal clades of Agaricales. Proceedings of the Royal Society of London, B 279: 2003-2011.

Sanmartin I, Ronquist F (2004) Southern Hemisphere biogeography inferred by event-based models: plant versus animal patterns. Systematic Biology 53: 216-243.

Stamatakis A (2006) RAxML-VI-HPC: maximum likelihood-based phylogenetics with thousands of taxa and mixed models. Bioinformatics 22: 2688-2690.

Stamatakis A (2014) RAxML 8: a tool for phylogenetic analysis and post-analysis of large phylogenies. Bioinformatics 30: 1312 1313.

Tedersoo L, Bahram M, Jairus T, Bechem E, Chinoya et al. (2011) Spatial structure and the effects of host and soil environments on communities of ectomycorrhizal fungi in wooded savannas and rain forests of continental Africa and Madagascar. Molecular Ecology 20: 3071-3080.

Tedersoo L, May TW, Smith ME (2010) Ectomycorrhizal lifestyle in fungi: global diversity, distribution, and evolution of phylogenetic lineages. Mycorrhiza 20: 217-263. 
Tedersoo L, Naadel T, Bahram M, Pritsch K, Buegger F, et al. (2012) Enzymatic activities and stable isotope patterns of ectomycorrhizal fungi in relation to phylogeny and exploration types in an afrotropical rain forest. New Phytologist 195: 832843.
Watling R (2001) An unusual Inocybe sp. from West Africa. Czech Mycology 52: 329-334. 